\title{
Towards A Peaceful Society: Job Involvement of Personnel of the Nigerian Police and Some Human Activator Variables
}

\author{
A. O. Ogunyemi ${ }^{1}$ S. S. Fasanmi ${ }^{1}$ E. O. Adesoye $^{2}$
}

Received: 29 January 2018/ Accepted: 11 September 2019/Published online: 28 March 2020

(C) The Author(s) 2020

\begin{abstract}
Job involvement is a relatively recent construct that could enhance employee performance. Previous research findings have shown strong associations between job involvement and organizational productivity, but very few studies have been conducted to examine the link between job involvement and some human activator variables (perceived organizational justice, organizational support, and group efficacy) among employees in Nigerian organizations. This study therefore employed a correlational design to investigate this link using 200 personnel of the Nigerian police chosen through disproportional stratified sampling. Results suggest that job involvement correlates significantly with the three predictor variables: procedural justice, perceived organizational support, and group efficacy. It was also found out that and the predictor variables accounted for $52.2 \%$ of the variance in the job involvement among Nigerian Police Force. It was recommended, among other things, that psychological intervention programmes that could enhance job involvement of Nigerian police personnel be introduced by government.
\end{abstract}

S. S. Fasanmi

fasanmisamuel@yahoo.com;

ss.fasanmi@oouagoiwoye.edu.ng

A. O. Ogunyemi

ogunyemijibola@gmail.com; bolaogunyemi@ymail.com

E. O. Adesoye

oyetemma@yahoo.com

1 Department of Psychology, Faculty of the Social Sciences, Olabisi Onabanjo University, Ago-Iwoye, Nigeria

2 Department of Educational Foundations and Counselling, Faculty of Education, Olabisi Onabanjo University, Ago-Iwoye, Nigeria
Keywords Group efficacy · Organisational support · Job involvement $\cdot$ Procedural justice

\section{Introduction}

Arising from continuous increase in population and advancement in technology, all human societies are in a continuous state of development; the intensity of interpersonal relationships among individuals and groups has increased tremendously. However, these greater interactions among people coupled with rapid population growth and urbanization have led to an unprecedented upsurge in the incidence of crime. It is the attempt to minimize crime and generally guarantee the security of lives and property that has led to the establishment of the police force all over the world. Despite the fact that the Nigerian police (formerly the Nigerian Police Force) has been on ground for over a century, attaining of its main goal of guaranteeing peace and security for residents in the country is still being threatened.

The history of the Nigerian police could be traced to 1861. It began with the establishment of a thirty-member Consular Guard in the Lagos Colony. This Guard was charged with the responsibility of protecting the property of the colonial government and was dominated by the Hausa/Fulani for which reason it was known as the Hausa Constabulary. The Lagos police was established in 1896 while the Niger Coast Constabulary with headquarters in Calabar was formed in 1894. Meanwhile, in Northern Nigeria, the Royal Niger Company had established the Royal Niger Company Constabulary in 1888. At the turn of the twentieth century, the British government proclaimed the Northern and Southern Protectorates. The Constabularies in the North and South were transformed into 
Northern Nigerian Police Force and Southern Nigerian Police Force, respectively. However, with the amalgamation of the Northern and Southern Protectorates and the subsequent creation of Nigeria in 1914, the Northern and Southern Nigerian Police Forces transformed into the Nigerian Police Force with headquarters in Lagos (Aremu, 2004). Initially, the Nigerian Police Force was under the control of the local or native authorities until the country attained independence in 1960 when it came under the control of both the regional and national governments. At that time, the Nigerian police was noted for dedication to duty, honesty, integrity, and patriotism (Aremu, 2004).

Recently, however, the Nigerian police has become notorious for inefficiency, corruption, exploitation, and impunity (Afolabi \& Adesina, 2006). It got so bad that the Nigerian police was recently rated as the worst in the world. It is characterized by indiscipline, lack of commitment, corruption of all sorts, extrajudicial killings, and incompetence, to mention but a few (Ehindero, 2006; Nwozor, 2005; Okoiye, 2011; Okusanya, 2006). Hence, many Nigerians now look down on the Force and regard its personnel as agents of death, corruption, oppression, suppression, and manipulation who blindly carry out the dictates of political office holders and the rich.

According to Aremu (2005), the level of job involvement of the personnel of the Nigerian police in genuine policing is a source of great concern to the government and citizens. He affirmed that the image of the Nigerian police has seriously deteriorated. It is the bid to recreate its positive image that led to the establishment of the Nigerian Police Service Commission in 1999. Successive governments from 2011 to date have been trying to improve on the performance of the Force through budgetary allocations. For instance, between 2011 and 2015, a total of N4.62tn was the nations' budget for security, out of which N1.55tn was earmarked for the Nigerian Police Force (Umeagbalasi, 2014). In the 2012 budget of N4.877tn, N921 bn was spent on security alone, out of which the Nigerian Police Force got N307.5bn. In the 2013 budget of N4.987tn, N953bn was spent on security, out of which the Nigerian Police Force got N320bn, and in the 2014 budget of N4.695tn, N993bn was spent on security, out of which the Nigerian Police Force was allocated N292bn. The 2015 budget estimate of the Nigerian Police Force is \#329bn, out of which \#306bn was earmarked for personnel (Umeagbalasi, 2014). In the 2016 budget, N927bn was spent on security, out of which N300bn went to the Nigerian police. In the 2017 budget, N1.12tn was spent on security, out of which N339bn went to the Nigerian police. But how this has assisted in improving efficiency and performance of an average Nigerian police is a question begging for an answer.

Since the late 1990s, the Nigerian police has launched several operations to combat crime and secure lives and property in the country. Some of these include Operation Sweep, Operation Flush, Operation Fire for Fire, AntiCrime Patrol, and so on. All these are efforts geared towards ensuring peace and better security of lives and properties in the country; but the extent to which all these measures have assisted the police in achieving its goal of creating a peaceful society with minimal incidences of brigandage of all sorts such as cultism, illegal oil bunkering, kidnapping, theft, armed robbery, and all forms of terrorist activities in the country is a cause for worry. Several training and retraining exercises, seminars, and conferences organized by successive governments in the past and which were aimed at developing and repositioning the Force for efficiency and better service delivery have not yielded the desired results.

The effectiveness of the personnel of any organization is determined by relating actual performance with a predetermined standard or expected performance (Ogunyemi et al., 2015). One of the major criticisms often levelled against members of the Nigerian police apart from corruption which has become a plague, is the non-committal attitude of its personnel to the vision statement of the body which is to build, through effective policing, an egalitarian society that is relatively free of any kind of insecurity. For example, cases abound where members of the Force were informed of an intending evil or an ongoing crime like robbery by members of the public, and rather than rising to the occasion, the police often disappoint by either not responding to such distress calls or by giving flimsy excuses (Aremu, 2004, 2009). All these indicate that a lot still needs to be done for the nation to have the kind of Police Force she deserves.

This becomes imperative particularly, when viewed against the backdrop that, since 1999, it is gradually becoming a norm for successive presidents and governors at the State and Federal levels to embark on overseas trips with ministers, commissioners, advisers, and other categories of political office holders in their entourage, all with a sole aim of attracting foreign investors to the nation. The idea is laudable, particularly now that the nation is passing through economic recession and fall in the price of crude oil in the world market. However, for a nation to woo foreign or even local investors, it must be able to protect lives and property of its citizens, and foreigners residing in it must not be in doubt about the safety of their investment. Some people have argued that not until the police sector, among other security agencies, is alive to its responsibility of ensuring adequate security of lives and property by maintaining law and order, efforts aimed at promoting foreign investment will not yield the desired results. This study is motivated by this realization.

Job involvement is a type of behaviour that can be described as the extent to which an employee is immersed 
in his or her job (Diefendorff, Brown, Kamin \& Lord, 2002; Kanungo, 1982a). It is the degree to which a worker identifies psychologically with the job (Nazeem \& Mozaiini, 2014). Job involvement has been recognized as a predictor of both employee and organizational outcomes (Lawler, 1986; Mgedezi, Toga, \& Mjoli, 2014). Employees with high levels of job involvement are more emotionally committed to their jobs (Hackett, Lapierre, \& Hausdorf, 2001). They are likely to be more punctual at work than employees with lower levels of job involvement (Blau \& Boal, 1987). Thus, job involvement has a negative association with intentions to quit and a positive relationship with job satisfaction (Chi-Shun \& Cheng-Wen, 2009; McElroy, Morrow, Crum, \& Dooley, 1995; McElroy, Morrow, \& Wardlow, 1999) and positive job attitudes (Diefendorff et al., 2002; Rotenberry \& Moberg, 2007).

Examining factors that can predict the job involvement of Nigerian police personnel who are known for gross inefficiency (Aremu, 2009), poor performance (Keyamo, 2006), and poor attitudes to work (Afolabi \& Adesina, 2006) may be a step in the right direction towards building an egalitarian society where peace and tranquillity reign supreme. Furthermore, previous studies have confirmed that job involvement contributes considerably to organizational performance (Nazeem \& Mozaiini, 2014; Pfeffer, 1994). The assumption of the present study is that the research findings may be a good database for employee training and retraining, recruitment, promotion and placement exercises. It can also be a step forward towards weeding off uncommitted and recalcitrant personnel from the system and even leading to re-engineering of the entire security sector. This assumption stems from the fact that employees' work involvement promotes positive outcomes and minimizes the incidence of negative tendencies such as turnover and unexcused absence from work (Diefendorff et al., 2002; Rizwan et al., 2011).

The idea of procedural justice originates in the sphere of law. For the results of a trial to be fair, the procedure adopted must be fair (for example, laws relating to testimonies). The principle is common in the workplace as well. It relates to perceived fairness in the process of organizational decisionmaking. Procedural justice examines the degree of importance which individuals attribute to the way in which decisions are reached. People in organizations are careful about reaching decisions in a fair manner and also want others to regard their decisions as fair. In procedural justice, the emphasis is not on the results of the decision, but on the process/way in which the decision was reached (the extent of sharing in the decision, transparency, bias, attention, understanding) (Fasanmi, 2018). Procedural justice comprises the subjective aspects (the way in which a specific procedure is perceived) and objective aspects (the way in which a specific procedure is carried out de facto).
Procedural justice relates to the perception of fairness, the way in which decisions were reached vis-à-vis the distribution of resources (Folger \& Corpanzano, 1998). Justice in organizations can be manifested in matters relating to perceptions of fair pay and equal opportunities for recruitment and promotion among the police force.

Perceived organizational support is another independent variable investigated in this study, and it is an important factor that could enhance employees' job involvement (Rhodes \& Eisenberger, 2002) for a reasonable length of time. Perceived organizational support, which could increase employee commitment and performance, has been defined as the extent to which an organization values employees' contributions and cares about them (Tumwesigye, 2010). Perceived organizational support may likely lead to job involvement. For instance, Rhoades and Eisenberger (2002) found that fair treatment, manager's support, pay, and favourable job conditions were strongly associated with perceived organizational support. It has also been reported that perceived organizational support reinforces employees' effort in the organization, resulting in greater probability of achieving organizational goals (Allen, Shore, \& Griffeth, 2003). The organizational support theory maintains that employees reciprocate organizational support by working harder to help their organization achieve its goals (Aselage \& Eisenberger, 2003). Thus, organizational support significantly influences both job performance and organizational commitment (Aube, Rousseau, \& Morin, 2007; Maertz \& Griffeth, 2004; Maertz, Griffeth, Campbell, \& Allez, Maertz et al. 2007; Rhodes \& Eisenberger, 2002; Riggle, Edmondson, \& Hansen, 2009). As such, since job performance, commitment, and involvement are positively associated in all kinds of work settings, the personnel of the Nigerian police cannot be an exception.

The work of policing, unlike other jobs, requires a lot of courage, determination, and commitment for an individual to succeed in it, and perceived organizational support meets the socio-emotional needs required by an average employee to persist. Ordinarily, perceived organizational support should motivate employees to put in more efforts in the performance of their tasks. According to the organizational support theory, employees' actions are influenced by the principle of reciprocity through which perceived organizational support increases their efforts and dedication to their organization (Chen, Eisbenger, Johnson, Sucharski, \& Aselage, 2009). Quite a number of studies indicate that workers with high levels of perceived organizational support have increased job satisfaction, positive mood, affective organizational commitment and performance, and less stress (Rhodes \& Eisenberger, 2002). But to what extent could perceived organizational support determine job involvement of the Nigerian police personnel? This is one of the questions to be answered in this study. 
Another issue of interest in this study is the centrality of group efficacy to employee's job involvement. According to Bandura (1995, 1997), group efficacy refers to a group's shared belief in its shared capabilities to organize and implement the activities required to produce given levels of attainments. Understanding how group motivation influences team performance is imperative because the work of policing, in most cases, requires team collaboration; it requires joint effort of individuals for better performance. Researchers across time and geographical areas are united in their findings that job involvement naturally results in employee motivation (e.g. Bashaw, \& Grant, 1994; Blau, 1986; Blau \& Boal, 1987; Hackett et al., 2001; McElroy et al., 1995), job satisfaction (Madsen, Miller \& John, 2005; Paterson \& O'Driscoll, 1990), and morale boosting (Mohsan et al., 2014; Rizwan et al., 2011). Thus, job involvement is strongly linked to employee motivation, organizational commitment, and performance. As such, these researchers are concerned with identifying a set of human activator constructs that can foster job involvement. This study therefore attempts to establish the composite and relative effects of perceived organizational justice, organizational support, and group efficacy on employees' job involvement.

The assumption of the present study is that the belief individuals in a group have about the ability of the group in achieving a set of tasks could be a source of motivation to members getting more involved or committed to their job. Bandura $(1995,1997)$ further suggested that groups build relationships through shared experiences, and this could enhance job involvement of employees. However, there is a dearth of research effort in this direction particularly, with personnel of the Nigerian police as participants. The main goal of the present study is to determine the most potent predictor of employees' job involvement among perceived organizational support, organizational justice, and group efficacy as well as how the predictor variables interact to predict job involvement.

\section{Hypotheses}

Equity theory, also known as justice theory, was developed by John Stacey Adams in 1963 and can be categorized as job motivational theory. It proposes that individuals determine whether the distribution of resources is fair to both relational partners (Brinkmann \& Stapf, 2005). In an organization, the equity theory of employee motivation describes the fair balance to be struck between an employee's inputs, such as hard work, skill level, tolerance or enthusiasm and an employee's outputs, such as salary, benefits or intangibles issues.
The theory claims that individuals in organizations compare the ratios of their own outcomes, normally tangible rewards, to inputs, such as contributions, to the ratios of other organizational referents. The comparisons will lead to adjustment of work behaviours. That is, when the comparisons yield big differences, people will be motivated to change the situation by either modifying their inputs or outcomes, changing their referent other, distorting their perception, or leaving the organization (Mitchell, Holtom, Lee, Sablynski, \& Erez, 2001).

In recent times, several arguments stressing the value of some psychological constructs such as job involvement among others in employee performance and organizational success have been canvassed. Many research findings (Meyer, Stanley, Herscovitch, \& Topolnytsku, 2002; Mgedezi et al., 2014; Mohsan, Nawaz, Khan, Shaukat, \& Aslan, 2014) have established the relationship between organizational environmental factors such as perceived organizational support and organizational justice and job performance of workers, with many stressing that environmental factors might influence the psyche of employees and subsequently affect their job attitudes and performance (Chandrasekar, 2001). A few studies (Pescosolido, 2003; Staijkovic, Lee, \& Nyberg, 2009) have also linked group variables, such as group efficacy among others, to employees' job commitment and productivity. Although it is generally agreed that availability and utilization of appropriate modern technological devices and equipment by workers could increase productivity, the role of the environmental variables investigated by the present study on employees' job involvement cannot be overemphasized since the quality of the work environment is fundamental to job involvement.

Empirical findings (Alemika \& Chukwuma, 2000; Aremu, 2006, 2009; Ehindero 2006) on organizational behaviour and employee performance, particularly those that used the personnel of Nigerian police as sample, have shown that lack of adequate equipment, up-to-date training, and communication skills, among others, are issues militating against effective policing in Nigeria. However, very little is known about the influence of work environment; despite the fact that the impact of environmental constructs on job attitudes and performance has been confirmed (Vischer, 2007). The central theme of this study therefore is the examination of the joint and relative contribution of perceived organizational justice, organizational support, and group efficacy to the prediction of job involvement among Nigerian police personnel.

Based on this premise, it is imperative to know whether perceived organizational justice, organizational support, and group efficacy will significantly, independently, and jointly predict involvement of personnel of the Nigerian 
police in Ogun East Senatorial District, Nigeria. Thus, this hypothesis states:

Perceived procedural justice, organizational support, and group efficacy will significantly, independently, and jointly predict involvement of personnel of the Nigerian police in Ogun East Senatorial District, Nigeria.

\section{Method}

\section{Design and Participants}

The ex-post facto survey research design was employed. This is because the independent variables being investigated have already occurred among the participants and the researchers were only interested in determining the influence of the predictor variables (perceived organizational justice, organizational support, and group efficacy) on the criterion variable (employees' job involvement) without manipulating or controlling any of the variables. This design was apt considering the fact that it is a non-experimental study where the independent variables could have been manipulated. This design was apt considering the fact that it is a non-experimental study where the independent variables could have been manipulated.

Data were culled from personnel of the Nigerian police across ranks and files from two area commands (Ijebu-Ode and Sagamu) in Ogun East Senatorial District. A total of 200 participants were included in the sample, chosen through the non-proportional stratified random sampling technique. One hundred respondents were selected from each of the police area commands in Ogun East Senatorial District. The sample comprised 80 constables $($ male $=63$, female $=17), 42$ corporals $($ male $=29$, female $=13), 52$ sergeants $($ male $=37$, female $=15), 19$ inspectors of police ( male $=17$, female $=2$ ), three assistant superintendents of police (all male), one deputy superintendents of police (all male), two superintendents of police (all male) and one chief superintendent of police (all male). However, out of the two hundred (200) questionnaires distributed, 188 (94\%) were returned, out of which only 182 (91\%) were properly filled by the respondents, and as such, used for analysis. The average length of service, which did not differ significantly between officers in the two area commands except for officers in assistant superintendent cadre and above, was 11.91 years $(\mathrm{SD}=8.95$, range $1-35)$. Their ages ranged between 23 and 57 years with the mean age of 32.6 years and standard deviation of 3.23.

\section{Instruments}

Four instruments were used to collect data for the study. The instruments are described below:

\section{Job Involvement Scale (JIS)}

Job involvement was measured with the 10-item Job Involvement Scale (JIS) developed by Kanungo (1982a). This scale measures the degree of psychological importance of one's job using a five-point Likert-type scale ranging from $1=$ strongly disagree to $5=$ strongly agree. Sample items on the scale included "I consider my job to be very central to my existence" and "I am very much personally involved in my job". The developer reported internal consistency reliability alpha coefficient of .86 for the scale. Kanungo (1982b) confirmed the construct validity of the JIS and found that it has a significant correlation with Work Ethics Scale (WES) (Mirels \& Garrett, 1991) and other work attitude measures. The alpha coefficient in the present study is .77 .

\section{Perceived Procedural Justice Scale (POJS)}

The 9-item procedural justice scale assessed whether respondents believed the processes the bank management uses when dealing with the downsizing issues are fair. The items were based on the work of Tyler (2003), and they measured four aspects of procedural justice: voice; respect; trustworthiness; and fairness. Items were measured on a 1 (strongly disagree) to 5 (strongly agree) scale, with higher scores indicating greater levels of perceived procedural justice. The author reported a reliability coefficient of 0.67 . A new reliability coefficient of 0.41 is reported in this study.

\section{Perceived Organizational Support Questionnaire (POSQ)}

The survey of Perceived Organizational Support Questionnaire (POSQ) developed by Eisenberger et al. (1986) to measure the extent to which respondents believed their organization values their contribution, considered their goals and interests, made help available to solve personal problems, and cared about their well-being was adopted for this study. Previous studies have affirmed the reliability and validity of this scale (e.g. Eisenberger et al. 1990; Shore \& Wayne, 1993).

\section{Group Efficacy}

The Collective Efficacy Beliefs Scale (CEBS) developed by Riggs and Knight (1994) was adapted for this study. The scale was adapted to measure group efficacy. It is a 7-item scale designed on a 6-point Likert-rating format with score ranging from $1=$ strongly disagree to $6=$ strongly agree. The scale was designed to measure the success of a group in performing a task; however, the format of the scale was also re-worded to reflect a 7-point Likert-rating since a 
7-point Likert scale captures responses more accurately than a 5- or 6-point Likert scale (Gonzalez, 2000). Some items on the scale were also reworded. For example, the original term "my department" is modified to "my group" to reveal the context accurately where they were having group work. The original seven items showed good internal consistency with an overall Cronbach's alpha $=.88$, but the Cronbach's alpha of the scale in the present study is 0.92 .

\section{Procedure}

The researchers personally administered the instruments at both area police headquarters, namely Ijebu-Ode and Sagamu Area police headquarters, with the permission and assistance of the area police commanders in the two police commands. Four weeks were used for the administration and collection of the questionnaires. Two hundred questionnaires were administered but only 182 were properly filled, giving an attrition rate of $9 \%$ (equivalent to a response rate of $91 \%$ ), which was considered adequate for analysis. The data sets obtained after scoring the instrument were analysed by means of multiple regression analysis and correlation matrices. Tests were carried out at the .05 significance level.

\section{Results}

A correlation matrix showing the significant relationship among the scaled variables is presented in Table 1. The essence of the correlation matrix was to establish the linear relationship among the variables.

The results in Table 1 showed the means and standard deviations of the variables in the study. Job involvement has a mean score of 72.06 and a standard deviation of 13.58; procedural justice has a mean score of 38.50 and a standard deviation of 14.35 ; perceived organizational support has a mean score of 24.16 and a standard deviation of 5.43, while group efficacy has a mean score of 29.97 and a standard deviation of 6.82 . The results also revealed that job involvement correlates significantly with procedural justice $(r=.526, p<.05)$, with perceived organizational support $(r=.687, p<.05)$, but not with group efficacy $(r=.041, p>.05)$. Also, the table showed that procedural justice and perceived organizational support are positively correlated $(r=.462, p<.05)$. However, perceived organizational support and group self-efficacy are not significantly correlated $(r=-.002 ; p>.05)$.

Hypothesis 1 stated that perceived procedural justice, organizational support, and group efficacy will significantly, independently, and jointly predict involvement of personnel of the Nigerian police in Ogun East Senatorial District, Nigeria.

The results in Table 2 showed that procedural justice $(\beta=.346, t=5.731 ; p<.01)$ and perceived organizational support $(\beta=.577, t=9.989 ; p<.01)$ had significant independent prediction on job involvement of personnel of the Nigerian police. However, group efficacy $(\beta=.054$, $t=1.025 ; p<.01)$ does not had significant independent prediction on job involvement of personnel of the Nigerian police.

Also, all the combination of independent variables (procedural justice, perceived organizational support, and group efficacy) significantly accounted for $52.2 \%$ of the variance in the job involvement of personnel of the Nigerian police $\left(F_{(3179)}=65.984 ; R_{(\mathrm{adj})}^{2}=.522 ; p<.05\right)$. In effect, procedural justice, perceived organizational support, and group efficacy will combine to predict police personnel job involvement.

\section{Discussion}

Attempt was made in this study to determine the interrelatedness and predictive power of perceived organizational support, procedural justice, and group efficacy on job involvement among personnel of the Nigerian police in Ogun East Senatorial District, Nigeria. This research focused on whether there is empirical backing for the ability of some human activator or psychological variables to improve job involvement of the Nigerian police personnel. Results demonstrated that the criterion measure has significant relationships with the three predictor variables (perceived organizational support, procedural justice, and group efficacy). By implication, the three predictor variables are capable of influencing the criterion measure; and this has significant implication for training and recruitment of personnel. The most notable findings revealed that about $52 \%\left(R_{(\mathrm{adj})}^{2}=.516\right)$ of the variance in job involvement of personnel of the Nigerian police was accounted for by the combination of the predictor measures; leaving about $48 \%$ accounted for by factors that were not considered in this study but which could also influence job involvement of personnel of the Nigerian police. Perceived organizational support will determine better the job involvement of personnel of the Nigerian police than any of the other predictor variables investigated in this study.

The high point of these findings is the fact that even though the combination of the three predictor variables will predict the criterion measure, group efficacy as a psychological construct is not an important or significant factor that can single-handedly influence the Nigerian police personnel's job involvement. All these findings provided additional insights into the relevance of psychological 
Table 1 Descriptive statistics and correlation matrix for the relationship among study variables

\begin{tabular}{|c|c|c|c|c|c|c|}
\hline & Mean & SD & 1 & 2 & 3 & 4 \\
\hline Job involvement & 72.06 & 13.58 & 1 & $.526^{*}$ & $.687 *$ & .041 \\
\hline Procedural justice & 38.50 & 14.35 & & 1 & $.462 *$ & $.242 *$ \\
\hline $\begin{array}{l}\text { Perceived organizational } \\
\text { support }\end{array}$ & 24.16 & 5.43 & & & 1 & -.002 \\
\hline Group efficacy & 29.97 & 6.82 & & & & 1 \\
\hline
\end{tabular}

*Correlation is significant at 0.05 level (two-tailed)

Table 2 Summary of regression analysis of variables predicting job involvement

\begin{tabular}{lllllllr}
\hline Variables & $\beta$ & $t$ & $p$ & $R$ & $R^{2}$ & Adjusted $R^{2}$ & $\mathrm{~F}$ \\
\hline Procedural justice & .346 & 5.731 & $<.01$ & & & & \\
Perceived organizational support & .577 & 9.890 & $<.01$ & .762 & .541 & .522 & 65.984 \\
Group efficacy & .054 & 1.025 & $>.01$ & & & & $<.01$ \\
\hline
\end{tabular}

variables to job involvement of workers, particularly personnel of the Nigerian police in the Ogun East Senatorial District, Nigeria. In other words, the findings affirm the potency of perceived organizational support and procedural justice as useful psychological tools for behaviour change. The lesson here is that some things such as sophisticated weapons which many believe are the main or only thing necessary in effective policing may be important in achieving quick result truly, but it may not be an end in itself as it seems to be referred, in most quarters, but a means to an end.

The findings of this study also imply that if the predictor measures investigated by the study are given their right place, particularly, POS both at the point of recruiting officers (may be by factoring it in the interview/recruitment process) and being made an important factor in the training and re-training process, there may be a significant improvement in the job involvement of the personnel of the Nigerian police. High levels of perceived organizational support have been associated with feelings of congruence between employees and their organizations (Rhoades \& Eisenberger, 2002), and this has implication for improved employees' job performance and organizational effectiveness and productivity. For example, the average employee reciprocates support received from the organization by exerting greater effort in the performance of his/her tasks. (Sherony \& Green, 2002). These findings agreed with the argument of Cherniss (2001) that organizational climate that supports individuals in their careers are important factors in managing employees in the Nigerian police.

These results also supported Chieh-Peng and Mei-Fang (2004) who established that the support personnel of the police force receive from the organization encourages and strengthens such officer to remain with the organization. It also corroborates previous findings of Cohen and Spector (2001) which affirmed that employees are more involved in an organization when they perceive that organizational justice and fairness prevail. Such employees will become assured of the security of their job and consequently experience low or no turnover while working hard towards the achievement of the goals of the organization. The finding is also in agreement with the assertion of Tyler (2009) that people expect an organization to employ neutral decision-making procedures enacted by trustworthy authorities, to help all group members benefit from belonging to the group.

Findings are actually expected considering the significant joint prediction of the three predictor variables of group efficacy, justice, and support on the Nigerian police personnel's job involvement. Also, it does not belie the postulations of Adam's equity theory, as personnel of the Nigerian police are wont to perceive that the distribution of resources is always unfair to them. Thus, it can be said that the objectives of this study are met with considerable and modest research findings achieved in the study.

\section{Implications of Findings}

The findings from this study have implications for counselling, policing, theory, and research. The findings have shown the practical relevance of perceived organizational justice and organizational support in improving job involvement among Nigerian police personnel. The implication of this is that correctional and industrial psychologists could introduce and apply special psychological intervention programmes for the management and 
improvement of job involvement of men and officers of the Nigerian police.

Further implication of this study is that the management of the Nigerian police could ensure that procedural justice is applied in every facet of management decisions to ensure that every employee receives a fair treatment. This will increase job satisfaction, cooperation, and collaboration among organizational members and enhance job involvement. Finally, the findings of this study also suggest that the work environment needs to be made more conducive and tension-free in order to increase job involvement. Conclusively, men and officers of the Nigerian police need to be valued, respected, and assisted by members of the public in order to make them more involved in and dedicated to their job.

Structural equation model that will reflect the path of each exogenous variable on the dependent variable and also accommodate the mediating variables of social factors will make more robust methodical and statistical impacts on the future-related study.

Open Access This article is distributed under the terms of the Creative Commons Attribution 4.0 International License ( http://creativecommons.org/licenses/by/4.0/), which permits unrestricted use, distribution, and reproduction in any medium, provided you give appropriate credit to the original author(s) and the source, provide a link to the Creative Commons license, and indicate if changes were made.

\section{References}

Afolabi, A. O., \& Adesina, A. A. (2006). Influence of job frustration, narcissism and demographic variables on attitudes towards professional ethical behaviour among Nigerian Police officers. African Journal of Psychological Studies and Social Issues, 9(1), $37-45$.

Alemika, E. O., \& Chukwuma, C. I. (2000). Police-community violence in Nigeria. Lagos: Malthouse Press Limited.

Allen, D. G., Shore, L. M., \& Griffith, R. W. (2003). The role of perceived organisational support and supportive human resource practices in the turnover process. Journal of Management, 29(1), 99-103.

Aremu, A. O. (2004). Beyond police barracks: A research synthesis of a counselling psychologist. Ife Psyhcologia: An International Journal of Psychology in African, 13(1), 214-226.

Aremu, A. O. (2005). A confluence of credentialing, career experience, self-efficacy, emotional intelligence, and motivation on the career commitment of young police in Ibadan. Policing: An International Journal of Police Strategies and Management, 28(4), 609-618.

Aremu, A. O. (2006). Impact of some demographic variables on job satisfaction of women police in Ibadan, Nigeria. University of Ibadan, Nigeria (submitted)

Aremu, A. O. (2009). Understanding the Nigerian police: Lessons from psychological research. Journal of Multidisciplinary Research, 4(8), 127-133.

Aselage, A., \& Eisenberger, B. J. (2003). Perceived organizational support and psychological contracts: a theoretical integration. Journal of Organisational Behaviour, 24(5), 491-509.
Aube, C., Rousseau, V., \& Morin, E. M. (2007). Perceived organizational support and organizational commitment: The moderating effect of locus of control and work autonomy. Journal of Managerial Psychology, 22(5), 479-495.

Bandura, A. A. (1995). Exercise of personal and collective efficacy in changing societies. In A. Bandura (Ed.), Self-efficacy in changing societies. New York: Cambridge University Press.

Bandura, A. A. (1997). Self-efficacy: The exercise of control. New York: Freeman.

Bashaw, R. E., \& Grant, E. S. (1994). Exploring the distinctive nature of work commitments: Their relationships with personal characteristics, job performance, and propensity to leave. Journal of Personal Selling \& Sales Management, 14(2), 1-16.

Blau, G. J. (1986). Job involvement and organizational commitment as interactive predictors of tardiness and absenteeism. Journal of Management, 12, 577-584.

Blau, G. J., \& Boal, K. B. (1987). Conceptualising how job involvement and organizational commitment affect turnover and absenteeism. The Academy of Management Review, 12, 288-300.

Chandrasekar, K. (2001). Workplace environment and its impact on organizational performance in public sector organizations. International Journal of Enterprise Computing and Business Systems, 1(1), 120-134.

Chen, Z., Eisbenger, R., Johnson, K. M., Sucharski, I. L., \& Aselage, J. (2009). Perceived organisational support and extra-role performance: Which leads to which? The Journal of Social Psychology, 149(1), 119-124.

Cherniss, C. (2001). Career commitment in human service professionals: A biographical study. Human Relations, 44(5), 419-437.

Chi-shun, L., \& Cheng-Wen, L. (2009). An empirical study of employee job involvement and personality traits: The case of Taiwan. International Journal of Economics and Management, $3(1), 22-36$.

Chieh-Peng, L., \& Mei-Fang, C. (2004). Career commitment as a moderator of the relationships among procedural justice, perceived organizational support, organizational commitment, and turnover intentions. Asia Pacific Management Review, 9(3), $519-538$.

Cohen-Charash, Y., \& Spector, P. E. (2001). The role of justice in organizations: A meta-analysis. Organizational Behaviour and Human Decision Processes, 86(2), 278-321.

Diefendorff, J., Brown, D., Kamin, A., \& Lord, B. (2002). Examining the roles of job involvement and work centrality in predicting organizational citizenship behaviours and job performance. Journal of Organizational Behaviour, 23, 93-108.

Ehindero, S. (2006). State of the nation. Sunday Vanguard Newspaper, p. 12.

Eisenberger, R., Fasolo, P., \& Davis-LaMastro, V. (1990). Perceived organizational support and employee diligence, commitment and innovation. Journal of Applied Psychology, 75, 51-59.

Eisenberger, R., Huntington, R., Hutchison, S., \& Sowa, D. (1986). Perceived organizational support. Journal of Applied Psychology, 71, 500-507.

Fasanmi, S. S. (2018). Effects of commitment, justice and empowerment on organisational citizenship behaviour and turnover intent among Nigerian bankers. Ife PsychologIA, 26(1), 16-44.

Folger, R., \& Cropanzano, R. (2001). Fairness theory: Justice as a ccountability. In J. Greenberg \& R. Folger (Eds.), Advances in organizational justice (pp. 1-55). Lexington, MA: New Lexington Press.

Gonzalez, M. G. (2000). The effects of task cohesion, interpersonal attraction, and collective efficacy on the performance of distance collaboration groups. Unpublished Doctoral Dissertation, Tulane University, New Orleans, LA. 
Hackett, R. D., Lapierre, L. M., \& Hausdorf, P. A. (2001). Understanding the links between work commitment constructs. Journal of Vocational Behaviour, 58, 392-413.

Kanungo, R. N. (1982a). Measurement of job and work involvement. Journal of Applied Psychology, 67, 341-349.

Kanungo, R. N. (1982b). Work alienation: An integrative approach. New York: Praeger.

Keyamo, F. (2006). Understanding I.G.'s frustration. Sunday Sun Newspaper, p. 4.

Lawler, E. E. (1986). High involvement management: Participative strategies for improving organizational performance. San Francisco: Jossey-Bass.

Madsen, S. R., Miller, D., \& John, C. R. (2005). Readiness for organizational change: Do organizational commitment and social relationships in the workplace make a difference? Human Resource Development Quarterly, 16(2), 213-233.

Maertz, C. P., \& Griffeth, R. W. (2004). Eight motivational forces and voluntary turnover: A theoretical synthesis with implications for research. Journal of Management, 12, 630-667.

Maertz, C. P., Griffeth, R. W., Campbell, N. S., \& Allen, D. G. (2007). The effects of perceived organisational support and perceived supervisor support on employee turnover. Journal of Organizational Behaviour, 28(8), 1059-1075.

McElroy, J. C., Morrow, P. C., Crum, M. R., \& Dooley, F. J. (1995). Railroad employee commitment and work-related attitudes and perceptions. Transportation Journal, 3, 13-24.

McElroy, J. C., Morrow, P. C., \& Wardlow, T. R. (1999). A career stage analysis of police officer work commitment. Journal of Criminal Justice, 27(6), 507-516.

Meyer, J. P., Stanley, D. J., Herscovitch, L., \& Topolnytsky, L. (2002). Affective, continuance and normative commitment to the organization: A meta-analysis of antecedents, correlates, and consequences. Journal of Vocational Behaviour, 61, 20-52.

Mgedezi, S., Toga, R., \& Mjoli, T. (2014). Intrinsic motivation and job involvement on employee retention: Case study-A selection of Eastern Cape Government Departments. Mediterranean Journal of Social Sciences, 5(20), 154-172.

Mirels, H. L., \& Garrett, J. B. (1971). The Protestant work ethic as a personality variable. Journal of Consulting and Clinical Psychology, 36, 40-44.

Mitchell, T. R., Holtom, B. C., Lee, T. W., Sablynski, C. J., \& Erez, M. (2001). Why people stay: Using job embeddedness to predict voluntary turnover. Academy of Management Journal, 44(6), $1102-1121$.

Mohsan, F., Nawaz, M. M., Khan, S. M., Shaukat, Z., \& Aslan, M. (2014). Are employee motivation, commitment and job involvement inter-related? Evidence from banking sector of Pakistan. International Journal of Business and Social Science, 2(17), 87-99.

Nazeem, F., \& Mozaiini, M. (2014). Investigating the relationship between the organisational commitment and job involvement in employees at Islamic Azad University of Roudehen Danavand, Pardis and Boomehen to provide appropriate model. Bulletin of Environment, Pharmacology and Life sciences, 3, 107-113.

Nwozor, N. (2005). Balogun faces new charges of graft, theft. New Age Newspaper, pp. 1-4.

Ogunyemi, A. O., Akinlaja, S. O., Adesoye, E., Akindele-Oscar, A., Azeez, R. O., \& Omolade, M. A. (2015). Organizational variables and effective performance of employees in oil and gas sector: An empirical investigation. International of Psychological Studies, 7(1), 23-31.
Okoiye, O. E. (2011). The inclusion of emotional intelligence in Nigerian police recruits' training programme: Agenda for police personnel pro-social development and effective policing. Journal of Research in Education and Society, 2(1), 61-70.

Okusanya, I. O. (2006). Police: A cult. The Punch Newspaper, p. 17.

Paterson, J. M., \& O’Driscoll, M. P. (1990). An empirical assessment of Kanungo's (1982) concept and measure of job involvement. Applied Psychology: An International Review, 39, 293-306.

Pescosolido, A. T. (2003). Group efficacy and group effectiveness: The effects of group efficacy, overtime on group performance, and development. Small Group Research, 34(1), 20-42.

Pfeffer, J. (1994). Competitive advantages through people. Boston: Harvard Business School Press.

Rhoades, L., \& Eisenberger, R. (2002). Perceived organizational support: A review of the literature. Journal of Applied Psychology, 87(4), 698-714.

Riggle, R. J., Edmondson, D. R., \& Hansen, J. D. (2009). A metaanalysis of the relationship between perceived organizational support and job outcomes: Twenty years of research. Journal of Business Research, 62(10), 1027-1030.

Riggs, M. L., \& Knight, P. A. (1994). The impact of perceived group success-failure on motivational beliefs and attitudes: A causal model. Journal of Applied Psychology, 79(5), 755-766.

Rizwan, M., Khan, J. K., \& Sabor, F. (2011). Relationship of job involvement with employee performance: Moderating role of attitude. European Journal of Business and Management, 3(8), 231-273.

Rotenberry, P. F., \& Moberg, P. J. (2007). Assessing the impact of job involvement on performance. Psychology, 63, 53-61.

Sherony, K. M., \& Green, S. G. (2002). Co-worker exchange: Relationships between co-workers, leaders-member exchange and work attitudes. Journal of Applied Psychology, 87, 542-548.

Shore, L. M., \& Wayne, S. J. (1993). Commitment and employee behaviour: comparison of affective organizational commitment and continuance commitment with perceived organizational support. Journal of Applied Psychology, 78, 774-780.

Staijkovic, A. D., Lee, D., \& Nyberg, A. J. (2009). Collective efficacy, group potency and group performance: Meta-analyses of their relationship, and test of a mediation model. Journal of Applied Psychology, 94(3), 814-828.

Tumwesigye, G. (2010). The relationship between perceived organizational support and turnover intentions in a developing country: The moderating role of organizational commitment. African Journal of Business Management, 4(6), 942-952.

Tyler, T. R. (2003). Procedural justice, legitimacy, and the effective rule of law. Crime Justice, 30, 431-505.

Tyler, T. R. (2009). The psychology of procedural justice: A test of the group-value model. Journal of Personality and Social Psychology, 57(6), 830-838.

Umeagbalasi, E. (2014). Spending for mass murderer. International Society of Civil liberties and the Rule of Law. Retrieved on 24th October, 2017 from http://newsrescue.com.

Vischer, J. C. (2007). The effect of the physical environment on job performance: Towards a therapeutic model of workspace stress. Journal of Stress and Health, 23, 175-184.

Publisher's Note Springer Nature remains neutral with regard to jurisdictional claims in published maps and institutional affiliations. 